\title{
Economic Security in the Barents Region
}

\section{Petrétei, Anna}

Routledge

2018

Petrétei , A \& Cambou , D 2018 , Economic Security in the Barents Region . in K Hossain \& D Cambou (eds), Society, Environment and Human Security in the Arctic Barents Region . Routledge, pp. 58-74 .<

https://www.routledge.com/Society-Environment-and-Human-Security-in-the-Arctic-Barents-Region/Hossain-Cambo $>$

http://hdl.handle.net/10138/313308

cc_by_nc_nd

publishedVersion

Downloaded from Helda, University of Helsinki institutional repository.

This is an electronic reprint of the original article.

This reprint may differ from the original in pagination and typographic detail.

Please cite the original version. 


\title{
2.2 Economic security in the Barents Region
}

\author{
Anna Petrétei and Dorothée Cambou
}

This chapter analyses economic security in the Barents Region. Economic security is one of the indicators for human security (UNDP 1994, 24), and is intrinsically linked with other human security components.

\section{Definition}

Economic security is composed of basic social security, and defined by access to basic needs infrastructure pertaining to health, education, dwelling, information, social protection, and work-related security (ILO 2004). According to the UN Human Development Report, economic security requires an assured basic income for individuals, usually from productive and remunerative work or, as a last resort, from a publicly financed safety net. In this sense, the majority of the world's population may be deemed as economically insecure (UNDP 1994, 25). This is mostly due to the unstable world market, increasing job insecurity, and growing unemployment ratio. The situation is even worse in developing countries, where governments have less means to provide economic support. The UNDP also identifies disparities in economic opportunities as one of the emerging threats that constitutes the global framework of human insecurity (UNDP 1994, 34-35). Thus, economic security is closely intertwined with job and income security. Income security denotes adequate actual, perceived, and expected income, either earned or in the form of social security and other benefits (ILO 2004). For some communities such as local and indigenous peoples informal income also represents a substantial share of the income.

Several other factors contributing to income and economic security include: a satisfying employment rate, an adequate government financed social safety net, and a stable market. Employment rate is defined by the OECD as a measure of the extent to which available labour resources are being used. It is the ratio of the employed to the working age population. ${ }^{1}$ This indicator is seasonally adjusted and it is measured in terms of thousand persons aged 15 and over, and as a percentage of working age population. Employment rate is sensitive to economic cycles, and can be significantly impacted by existing government policies and public demographics. This includes the level of 
higher education achievable, the income support policies of governments, and policies that facilitate the employment of women and disadvantaged groups. Another contributing factor to economic security is the existence of a social safety net, defined as a collection of services provided by the state or other institutions such as friendly societies, including cash or food transfers, social services, such as health clinics; and insurance options (Gentilini \& Omamo 2009 , 2). Adequate government financed social safety nets often include maternity leave, welfare, unemployment benefit, universal healthcare, pension, homeless shelters, and sometimes subsidised services such as public transport, which are meant to prevent individuals from falling into poverty beyond a certain level. The UNDP suggests that a means of determining whether social safety is adequately ensured includes measuring homelessness as an indicator of insecurity (UNDP 1994, 26; UNDP 2016, 55).

When discussing economic security, the stability of the market is an important indicator to take into account. While it is difficult to appraise the stability of the market economy, several indicators may provide information about the economic situation of a country such as its GDP (Gross Domestic Product) and GRDP (Gross Regional Domestic Product). GDP embodies the market value of all products and services produced within a certain period, by all people and companies in the given country, whereas GRDP is the geographic breakdown of national GDP, indicating the size and structure of regional economies and measuring changes to regional economies over time. Although GDP is one of the most effective ways to measure the economic development of a country, GDP and GRDP are not good indicators of economic security per se. This is because GDP and GRDP are the main indicators of economic growth. Whereas economic security aims to ensure economic wellbeing, economic growth is a phenomenon of market productivity and rise in GDP or GRDP. Hence, as economist Amartya Sen indicates, 'economic growth is one aspect of the process of economic development', but it does not subsume such development (Sen 1983, 748).

Understanding that economic growth alone cannot properly determine the security or development of a country, it is therefore necessary to consider other indicators. A more inclusive indicator of economic development constitutes the human development indicator. The creation of the Human Development Index (HDI) emphasises that people and their capabilities should be the ultimate criteria for assessing the development of a country. The HDI is a summary measure of average achievements in three key dimensions of human development: a long and healthy life, education, and a decent standard of living, the latter being measured on the basis of the GDP per capita. The use of HDI overlaps with other aspects of human security as well, but in the case of economic security, it serves a more representative function than economic growth. However, several important aspects of human development are also not well represented in HDI, especially as it is difficult to use indicators like GDP per capita to measure the health of subsistence or mixed economies (AHDR 2004, 17). In this 
regard, HDI can be a valuable tool to assess economic security but certainly not the only one.

Lastly, addressing economic security requires interdisciplinary actions across sectors, communities, and political borders in order to ensure a more comprehensive overview of the matter. In the globalised free market, interaction between economies is essential and unavoidable, which consequently requires stable and peaceful political and economic relations across borders. In summary, economic security is far-reaching, and includes the need to address the relationships between various security aspects in both contemporary and future situations.

\section{Contextualisation}

The Barents Region has considerable economic potential and is exceptionally rich in natural resources. The economy of the Barents is also strong, with an overall positive GDP since the beginning of the 21st century (BEAC 2015, 14). Important drivers of the Barents Region's economy are forestry, metallurgy, mining, energy production, fisheries, and tourism. In terms of primary sectors, forestry and mining are important in all parts of the Barents Region, while fishing and energy (mainly oil and gas) are important in northern Norway and northwestern Russia. The Barents Region is also an important source of hydroelectricity and a growing market for wind energy, for both local use and for export outside the region. Tourism and reindeer husbandry are also important activities in the region. In some areas, such as northern Finland, the sector of tourism is an important source of employment, and its importance is growing in other parts of the region, especially in Norway (BIN 2017). In addition, the secondary workforce sector - processing, production, and construction - accounts for most work in Fennoscandia and some Russian areas. In the Nordic part of the Barents area, the services sector is the largest employer (AMAP 2017).

There are, however, still apparent economic divisions between the Nordic and Russian parts of the region as the Nordic countries enjoy substantially higher GDP per capita than Russian regions. In addition, it can be noted that there is also variation between Barents and non-Barents Regions within the same country. In the Northern areas of Norway, Sweden, and Finland, per capita economic growth has generally lagged behind the respective national averages (AMAP 2017, 11). This is mostly due to less diverse industrial bases and lower labour market participation (AMAP 2017, 11). In the Russian Federation on the other hand, the resource-rich Northern regions have the highest GDP per head compared to the national average (AMAP 2017, 11). On the other hand, Nordic countries currently enjoy substantially higher GDP per capita than regions in the Russian Federation.

Yet, the Barents Region has encountered the consequences of economic recession and looking at GRP is insufficient to assess the reality concerning the basis for economic livelihoods. In the Barents Region, job creation is 
generally lagging behind the national average and employment creation in the resources sector has significantly decreased since 2008 (BIN 2017). In the Nordic countries, the biggest job loss between 2008 and 2014 was observed in mining, quarrying and manufacturing (4,444 jobs), followed by agriculture, forestry, and fishing (2,270 jobs) (BIN 2017, 45). According to Business Index North (BIN), 'job losses in agriculture, forestry and fishing reflect the process of urbanisation in the northern parts of the Nordic area, combined with the modernisation of the industry' (BIN 2017,45). On the other hand, this has resulted in an increased demand for high-skill labour and an increase of job creation in the real estate, professional, scientific, and technical sector $(1,984$ jobs), followed by public administration, defence, and social security since 2008 (BIN 2017, 45). Analysis has also shown that the population in the Barents Region is generally ageing and becoming more urbanised, which has important economic and social consequences (AMAP 2017, 6). There is indeed important variation in unemployment and education rate between urban and non-urban areas (BEAC 2015, 15).

The level of prosperity also largely differs between the Russian and Nordic parts of the Barents Region. With the dismantling of the USSR, unemployment has increased, and a wider gap between rich and poor has appeared in Russia and its Barents Regions (Bahry, 2002; Duhaime and Caron 2008; Rosstat in Didyk 2012, 148). The poverty rate is reported to be between $20 \%$ and $25 \%$, affecting mostly single parent families and large families, and individuals with little education and those living in rural areas (Bahry, 2002; Duhaime and Caron 2008). In all of the regions of the Russian part of the Barents, the threshold value of the decile ratio, which indicates income inequality, was exceeded to varying degrees between 2003 and 2008 (Didyk 2012, 148). The changing role of the Russian state with the withdrawal of the government as producer and organiser 'have redrawn class boundaries, undermined traditional job guarantees and eroded the old social safety net' (Bahry, 2002; Duhaime and Caron 2008). Since the economic transition, the Russian Barents is also facing demographic challenges caused by a massive migration from the Arctic regions to the southern regions (Eikeland \& Riabova 2002). Life expectancy is also critically low. According to 2008 census, 'in none of the Barents Russian regions did life expectancy reach the "threshold" level used as a criterion for estimations of sustainability' and 'none of the BEAR regions reached the national average level of life expectancy' (Didyk 2012, 146). In fact, while all Russian regions of the Barents have improved their HDI during the period from 2003 to 2008, the index values are still below the national average and in Murmansk Oblast and Karelia the values are below the level which is considered the lower level for developed countries (0.8) (Didyk 2012, 145-146). As indicated by Duhaime and Caron $(2008,20)$, 'the socioeconomic conditions of the "New Russia", built on the Soviet ruins, thus reflect a greatly weakened social situation and a redistribution system which cannot even be qualified as a rudimentary welfare state'. 
By contrast, the Nordic countries have achieved some of the most favourable social conditions for human development in the Arctic Region (Duhaime and Caron 2008, 18). Poverty rates in Fenno-Scandinavia are lower than elsewhere, life expectancy and education level are the highest within the circumpolar Arctic, and infant mortality is the lowest (Glomsrød and Aslaksen 2009, 17-18). As a result, all three countries are ranked within the top 25 countries in the world HDI ranking (UN 2017). This is partly due to the social democratic tradition and the political redistribution of resources through social policies. All indicators show that redistribution policies have had beneficial effects on living conditions in the Arctic regions of the Fenno-Scandinavian countries (Glomsrød and Aslaksen 2009, 17-18). However, all regions of the Barents area are experiencing an ageing of its population, where the proportions of adults and elderly increase, while the proportions of children and adolescents decrease. This process results in a rise in the median age of the population and an increase in the dependence ratio which 'indicates growing pressures on social security and public health systems' (BIN 2017, 11). This situation can lead to serious problems in the economic and social sphere and could affect economic security in this part of the region as well. Furthermore, there are also income disparities that have been observed between the Sámi and other inhabitants. While the Sami people are certainly less impoverished than indigenous peoples in the Russian parts, it has been observed that the income for the area where Sami live in Norway is considerably lower than the average total household income for other northern areas (Glomsrød and Aslaksen 2009, 116-117). Additionally, it is also reported that Sámi living in Finland 'earn less than other inhabitants of the country and are under-represented on the job market and over-represented among the unemployed' (Duhaime and Caron 2008, 19). Thus, economic security varies between countries, east from west, and between peoples.

Beyond those differences, it can be noted that one of the common challenges faced by the Barents population is the development of sustainable and environmentally responsible economic activities (BEAC 2015, 16). Whereas extractive industries play a major role in the economy of the region, the pristine environment and its renewable resources are major sources of livelihoods for the Barents population in all parts of the region. Both the tourism industry, which is one of the most important sources of income in the Barents Region, and local and indigenous communities livelihoods depend on the sustainable management of the Barents environment. However, an increased demand for non-renewable resources in nature based activities has exacerbated existing conflicts between extractive and renewable industries, more particularly increasing tension on traditional hunting, fishing, and herding by indigenous peoples (BIN 2017, 8). Finally, the Barents economy is influenced by global development, whether through migration, trade, or geopolitical events (AMAP 2017). Although it is not possible to analyse or predict how this development may influence the region in the future, those are elements that also impact the state of economic security of the Barents population. 
Considering these contexts and issues, the following section assesses different aspects of economic (in)security that challenge the contemporary wellbeing of the Arctic population, focusing especially on the Barents Region.

\section{Assessment}

Economic security encapsulates complex and interlinked challenges, which highlight economic development as a means for achieving a larger sense of security, sustainability and wellbeing for peoples. This section focuses on some of the main economic security challenges faced by the population in the Barents Region. These diverse challenges include an assured access to employment, education, demography changes, transportation systems, sustainable development and the impact of mining industries on subsistence economies as well as the external effects of geopolitical and economic events on the region.

\subsection{Unemployment}

As already mentioned above, economic indicators reveal differences across countries in the Barents Region. One of the relevant indicators is unemployment, which is also one of the most commonly used tools to measure economic security. One of the major effects of unemployment is indeed its potential to drive individuals into poverty.

Unemployment rates vary significantly within the Barents Region, generally with Troms (Norway) having the lowest and Kainuu (Finland) having the highest ratio. In 2014, Troms had an unemployment rate of $1.6 \%$, while the ratio was $16.9 \%$ in Kainuu. The unemployment rate in other regions were as follows: $1.9 \%$ in Nordland (Norway), $2.4 \%$ in Finnmark (Norway), $7 \%$ in Västerbotten (Sweden), 7.7\% in Norrbotten (Sweden), 9.7\% in Lapland (Finland), $10.2 \%$ in Northern Ostrobothnia (Finland), 6.7\% in Murmansk (Russia), 8.1\% in Karelia (Russia), 6.2\% in Arkhangelsk (Russia), 6.1\% in Komi Republic (Russia), and 6.3\% in the Nenets Autonomous Okrug (BEAC 2015, 15). Generally, the unemployment rate in the Norwegian part of the Barents Region was lower than the national average, while in the other three Barents countries, the unemployment rate in the Barents Region was higher than in other parts of the countries. As the above figures show, the unemployment rate in different parts of the Barents Region vary from approximately $1.6 \%$ to $16.9 \%$, but there is no great discrepancy in the region overall.

As already mentioned, it has also been observed that the biggest employment losses which occurred in the Nordic part of the Barents Region concerns mining, quarrying, and manufacturing, followed by agriculture, forestry, and fishing (BIN 2017, 38). This trend reflects a decline in the employment share of middle-skilled and middle-waged occupations partly caused by growing automation in production, job outsourcing, and price competition from emerging countries, all which affect manufacturing jobs (BIN 2017, 38). Furthermore, there is also a high unemployment rate among young people 
(BEAC 2014, 2). As a consequence, and in order to increase economic security, an up to date assessment of the labour market situation and needs of the Barents population is necessary. Further research is also needed on how to support more favourable employment development in the overall region and increase new employment opportunities.

\subsection{Demographic changes}

The Barents Region faces significant demographic challenges due to its increasingly ageing population, and the trend of younger populations leaving the Barents Region to work in larger cities in the south of the respective countries (BEAC 2015, 5). Europe in general is currently the oldest continent with the highest old age dependency ratio, and according to projections it will remain so until 2060 (EU Commission 2014, 23). The implications of these demographic changes are even more severe for the Barents Region. The falling population trend is caused by negative net migration, and declining birth rate. Young and highly educated people are migrating mostly from peripheral towns to urban centres in the south. In the past decades the region has lost thousands of working-age citizens due to a lack of job opportunities, especially in the Russian regions and in the Kainuu region in Finland (BEAC 2015, 12).

Since 1990, the population has been declining in the Barents Region, especially in the Russian part. The greatest population decline is observed in Murmansk - in 2014, statistics showed a $35.29 \%$ decline compared to 1990 (Patchworkbarents in BEAC 2015, 13). In Arkhangelsk Oblast, the population between 1990 and 2015 changed from 1,575,502 to 1,183,323. The Komi Republic and the Republic of Karelia also experienced significant population decline within the same period. The population in the Komi Republic changed from $1,248,891$ to 864,424 , in the Murmansk Oblast from 1,191,468 to 766,300, whereas in Karelia from 791,719 to 632,500 (Patchworkbarents in BEAC 2015, 13). In other parts of the Barents Region, the demography changes have not been as harsh. Within 1990 and 2015, the population of the region has changed as shown in Table 2.2.1 (indicated in descending order in terms of population).

Although in some areas (for instance in Northern Ostrobothnia in Finland, Västerbotten in Sweden, as well as throughout the Norwegian Barents) statistics showed an increasing population between 1990 and 2014 (Patchworkbarents in BEAC 2015, 13), the total population in the Barents Region within that period still showed a decline of at least 20.93\% (BEAC 2015, 13). The general decline in population is largely due to the declining population in the Russian areas of the Barents Region. Furthermore, even if the Nordic part of the Barents have experienced a population growth, the declining population in the age group 0-19 and considerable increase in population for the age group 65+ may have long term implications for labour and education (BIN 2017). 
Table 2.2.1 Demographic trends in the Barents Region

\begin{tabular}{lll}
\hline & 1990 & 2015 \\
\hline Northern Ostrobothnia & 346,301 & 406,966 \\
Norrbotten & 263,735 & 249,777 \\
Västerbotten & 251,968 & 262,593 \\
Nordland & 239,532 & 241,682 \\
Lapland & 200,674 & 180,848 \\
Troms & 146,594 & 163,453 \\
Kainuu & 96,957 & 78,388 \\
Finnmark & 74,148 & 75,605 \\
\hline
\end{tabular}

Source: data from Patchworkbarents (BEAC 2015, 13)

The implications of these demographic changes are also important for transfer systems and the ratio of economic dependency. For instance, the Nordic parts of the Barents Region are experiencing an ageing of its population, where the proportions of adults and elderly increase, while the proportions of the youth decrease. Population in the age class $0-19$ in the Nordic parts of the Barents decreased by $5.9 \%$ while for the national average as a whole it grew by $1.9 \%$ in the $2006-2015$ period (BIN 2017, 18). Statistics also shows that in 2015 half of this area's population was older than 41.8 years, while the other half was younger. However, with a rise in the dependency ratio, there is a growing pressure on social security and public health systems in the region. In this context, important political and development measures should be taken, especially concerning the role of the elderly population as participants in the Barents economy (BIN 2017, 21).

\subsection{Education needs and resources}

A lack of access to quality higher education can also manifest in economic poverty and unemployment, resulting in insufficient economic resources. Conversely, prior studies indicate that highly educated peoples generally have better health and have higher employment rates and higher relative earnings (OECD, 2016 in BIN 2017, 36). Tertiary education also contributes to foster innovation, increases economic activities and growth, and contributes to the wellbeing of the population. In the Nordic countries, a growth in tertiary education has been observed but the percentage of the population aged 20-59 who have successfully completed tertiary studies still lag behind the national average (BIN 2017). This statistic indicates that policy actions could be envisaged to improve tertiary education in the Nordic countries.

In addition, it is also necessary to ensure proper primary and secondary education in the Barents Region. However, ensuring basic and adequate education is challenging for communities inhabiting remote areas. The most 
significant challenges are the consolidation and closing of small, remote schools, providing sufficiently comprehensive education opportunities, as well as recruiting and retaining teachers in remote communities (Larsen and Fondahl 2015, 351). Shrinking populations in remote parts of the Barents also constitute a challenge to maintaining access to education services (BIN 2017, 37). Another important factor includes language instruction, especially with regard to the efforts to retain traditional languages (i.e. languages other than the dominant language in a given society, such as for example Sámi languages) and to ensure that students acquire the national languages of commerce and higher education. In addition, finding new ways to use and transmit indigenous knowledge, the gender pay gap, as well as the continuing underperformance of indigenous students across most parts of the North are all relevant social issues that influence individuals' access to economic opportunities (Larsen and Fondahl 2015, 351).

\subsection{Transportation and infrastructure}

Interaction between citizens, businesses, and other civil society actors is an important factor for broader economic growth and economic security. In the Barents Region, this interaction is intrinsically dependant on adequate transportation and infrastructure systems. Moreover due to the fact that population density in the Barents Region is low, and the main markets for raw materials and refined products are located outside the region, transport and infrastructure have significant importance in the Barents. The significance of transportation is also reflected in other aspects, such as its impact on food costs, business development, and cultural relationships between peoples and communities.

Specifically, large quantities of time-sensitive seafood are delivered to both western and eastern Europe, but transport is also important for other sectors of the economy. Raw materials and manufactured products from the mining, metal, and forest industries also need to be transported to Europe for further processing. Asia and America are also important markets for raw materials (BEAC Transport Area 2013, 37). Some raw materials and manufactured products are also traded within the Barents Region. For instance, ore from Russia and Sweden are transported for processing in Finland, and seafood from Northern Norway is delivered across the region. However, the largest intra-Barents flows are transit flows: for instance, half of the farmed salmon produced in Northern Norway passes through Northern Sweden and/or Northern Finland on its way to the market. For example, farmed salmon from Northern Norway is transported by road to Helsinki, where it is made ready for further transport by plane from Helsinki to Asia for distribution. Also, iron ore from Northern Sweden transits Northern Norway on its way to the biggest markets. Oil and gas extracted in the Russian Federation is transported along the coast of Norway, but mainly through international waters. Furthermore, there are a number of traffic hubs in the region where re-loading between different types of traffic can take place. In larger places there are strategic cargo nodes, which are intermodal, whereas in other 
places there are railway stockyards or port facilities. (BEAC Transport Area 2013, 37-38).

The importance of transportation in the region is therefore evident. The existence of a strong transportation infrastructure is not only crucial for the rapidly expanding industries and for the development of remote areas, but also contributes to economic stability and mobility of labour. However, interaction between citizens, businesses, and other civil society actors in the Barents Region is hampered by inadequate transportation and infrastructure systems (BEAC 2015, 16). While there is relative good transportation in a North-South direction, the lack of transport infrastructure East-West significantly hinders economic development across the borders of the Barents Region. In order to ensure smooth transportation and border crossings, wellfunctioning cross-border cooperation in the Barents Region is consequently required. More specifically developing East-West transport infrastructure is a key to business cooperation in the Barents Region and 'further extension of the traffic infrastructure eastwards appears to be vital' (BIN 2017, 93).

\subsection{Economic and sustainable development}

The economic security and wellbeing of the population depend in part on the living environment and natural resources of the Barents Region. Regional development needs to happen in concordance with preserving the environment, mitigating and adapting to climate change, and fostering good and healthy living conditions for the people. The attractiveness of the region in enticing people to live and work in the Barents Region, as well as for the establishment of businesses, is relevant to subsequent employment opportunities, education, health, culture, the surroundings, nature, and recreational activities (BEAC 2014, 4).

As a consequence of the growing global need for minerals and other natural resources, extractive industries are continuously expanding. As the Barents has already proven to be rich in natural resources, extractive industrial activities have become important contributors to the national economies of states. The development of national legislation and mineral strategies reflects the interest of states in the expanding potential of mining industries. For instance, the vast majority of the iron ore produced in the EU comes from Sweden, and the Swedish government has expressed its wish to strengthen its position as the leading mining nation in the EU (Swedish Ministry of Enterprise, Energy and Communications 2013). Furthermore, Finland is a global pioneer in the responsible use of minerals, and the country's legislation is amongst the most attractive for mining investments worldwide. The Norwegian government defined its mineral industry as a focal area, stating that it wants the country to be attractive for mining activities (Norwegian Ministry of Trade and Industry 2013). The Russian Federation is also exceptionally rich in natural resources, and subsoil resources significantly contribute to the country's economy (Pettersson et al. 2015, 247). 
As already mentioned, extractive industries play an important role in the economy of the region. However, the mining industry and other extractive development projects may have an adverse impact on the region's nature and environment, which may undermine environmental sustainability. While the reasonable and economic acquisition and use of mineral resources is gaining more and more significance (Dubiński 2013, 2), the impact of extractive industries in the Barents nevertheless constitutes a challenge for the Barents environment and other economic activities. This is the case with tourism, a main driver of economic growth in the Nordic countries and an integral part of the local economy in the Barents Region (AMAP 2017, 12). The construction of mining sites may damage the natural environment near the mine, which can be problematic as pristine nature is one of the most attractive factors for the tourism industry in the Barents Region. Ultimately, one of the main challenges faced by the region is therefore to ensure an adequate balance between competing interests and actors to ensure that they contribute to the economic, social, and environmental sustainable development of the entire population and communities living in the region.

Another challenge faced by the Barents population relates to the revenue generated by extractive industries and their impact on local population. Economic benefits from the activities of extractives industries are not always used for the benefit and interest of the local population. Despite the significant revenue generated by extractives industries in the Russian region, the share of the population living in this part of the region with income below subsistence level is critically high. In 2008, only in the Nenets Autonomous Okrug (AO) did the poverty level indicator "not exceed the "threshold" level when estimated in terms of the criteria for sustainable development'. In all other regions, the poverty level was considered critically high and incompatible with sustainable development (Didyk 2012, 147). Furthermore, although the poverty level of the Nenets AO is not considered critical, the level of income inequality is the highest in Russia. This is explained by the influence of extractive industries and simultaneous presence of low-income population living in this region (Didyk 2012, 148). This situation clearly demonstrates the importance of redistribution policies to alleviate income disparities, across the Barents, which should evidently been promoted in Russia.

Finally, another challenge concerns the impact of economic development on the subsistence economies of indigenous peoples. The Barents Region is home to several indigenous peoples, which also indicates different economic livelihoods. The livelihoods of indigenous peoples typically relate to land, water, and other natural resources. In the Barents Region, indigenous peoples have developed highly specialised livelihood strategies and occupations that include, among others, reindeer herding, hunting, fishing, trapping, shifting cultivation or gathering food and forest products, and, in some cases, handicrafts. They are therefore dependent on the rights to natural resources and the management of natural resources for their subsistence. Because of indigenous peoples' dependence on natural resources, their interest in preserving these 
resources in the long term is significant (Skogvang 2013). These livelihoods are not only a source of food and income for indigenous peoples, but are also a part of their heritage and culture.

Problematically, indigenous peoples's traditional livelihoods also compete with other societal interests (Allard 2006, 15), more particularly the need to increase economic development via the development of resource extractive projects. However, the extractive industries in the Barents Region are posing a real threat to the livelihoods of the indigenous peoples, such as the Sámi and the Nenets (Anaya 2011, para. 55; Tauli-Corpuz 2016, para. 86). In many cases, development projects represent a basis for conflicts between industries and the affected indigenous peoples. For instance, an important Sámi protest took place in Jokkmokk (Sweden) in 2013, when test mining permission was granted to a British mining company on reindeer grazing lands (Koivurova et al. 2015, 28). In addition, extractive industries also threaten the traditional way of life of indigenous peoples in the Russian Federation, such as the nomadic lifestyle (including hunting, fishing, and reindeer herding) of the Nenets people (Garipov 2014, 74-75; Anaya 2010).

Behind the impact of extractive industries, arctic indigenous peoples, such as the Sámi and Nenets, face other challenges due to environmental problems, for instance pollution and climate change, which seriously affect their rights to their traditional territories (Heinämäki 2004, 231-233). Ultimately, in order to ensure sustainable development for all in the Barents Region, policy actions should recognise and implement the rights of indigenous peoples in the region in a better fashion. Specifically, measures to include them in the decision-making processes concerning the development of their traditional land and territories should be promoted in order to ensure that their voice and interests are represented in the governance of their territories (See also chapter 2.8).

\subsection{External influences of geopolitics and financial events}

Economic security is also influenced by economic and geopolitical events. External economic and foreign policy instability can be responsible for unstable market and economic relations, which can affect the economic security of peoples at the local level. The 2008 global economic crisis has certainly influenced the Barents market. For instance, the impact on mineral and ore prices negatively influenced northern counties in both Sweden and Finland (BIN 2017, 91). Similarly, the Russian economy has been deeply affected by the fall of the global oil prices, leading to significant revenue shortfalls and recession in the country. As a result of the recession, Russia is reversing substantial achievement in poverty reduction. In 2015 , the poverty rate in the country increased from 11.2 to $13.4 \%$, as the poor population increased by 3.1 million to a total of 19.2 million (World Bank Group 2016, 8). In 2016, a further increase in poverty levels was projected, due to a continuing increase in unemployment and government's difficulty in enforcing poverty-reduction 
measures (World Bank Group 2016, 8). Thus, the Russian economy faces important challenges that are both induced by internal and external phenomena such the global financial crisis and lower oil prices. Although it is not defined how this trend has distinctively affected the Barents Region, there is no doubt that these developments have also negatively impacted its population.

In relation to the impact of external events on economic security, the consequences of the Ukrainian crisis on the Russian and Barents economy is another case in point. Following Russia's annexation of Crimea, the European Union responded with a series of sanctions, including asset freezes on key allies of President Putin, an arms embargo, restrictions on access to capital markets, and several other targeted measures. Furthermore, these measures were not limited to, or principally focused on the occupied territory, but were explicitly adopted as diplomatic tools in response to Russian actions. These sanctions had consequences for the Barents Region as well.

As a consequence of EU sanctions, Lapland, Northern Ostrobothnia, and Kainuu experienced a lower demand for paper and shrinking exports to Russia as well as reduced tourism inflows (BIN 2017, 8). Within the Barents Region, Finland and Norway have been disproportionately affected by Russian counter-sanctions on agricultural, livestock, and fishery products in comparison to other European countries (Larrabee et al. 2017, 27). Dairy farms were the most affected by counter-sanctions, and some were even forced to close down (Nilsen 2016). In addition, even though tourism in the Russian Barents had already been declining, the sector witnessed a 3\% drop by May 2014, reinforced by the political crisis (Nilsen 2014). As part of the sanctions, the defence industry struggled to replace Western arms imports, and energy companies had to deal with restrictions on energy cooperation with Russia. Furthermore, stability in business and banking sectors had to be managed due to financial restrictions (Russel 2016, 7-9). Finally, the 2014 crisis and subsequent sanctions have also had an 'impact on EU-Russia cooperation in many sectors and have blocked several of the previously available multilateral financing sources to foster the Barents cooperation' (BEAC 2015, 7).

In light of this, one important recommendation therefore lies in the need to enhance and strengthen economic cooperation across borders. Since administrative and political cooperation between members at the regional level of the Barents has continued and become stronger after the annexation of Crimea (Koivurova 2016), it is a primary concern to reinforce economic bonds in the region, a task that can be channelled via existing institutions. Enhancing the level of funding both for large scale and small-scale cross-border activities, and businesses, could also contribute to such a development, especially as 'the majority of Barents Regions consider the current level of financing insufficient for their joint activities' (BEAC 2015, 7). Among other actions, addressing structural constraints to investment in Russia would also help enhance longterm growth prospects (World Bank Group 2016, 8) and perhaps alleviate economic insecurity for the population. Thus, improving economic security 
requires a bundle of measures to be taken at the regional, national, and international levels.

\section{Conclusion}

Projections show that the world economy will grow at around 3\% per year over the next fifty years (although according to recent forecasts, this number will go down) but the OECD projects that the Barents countries will see economic growth rates below the world average. Nonetheless, all four countries will roughly double the size of their economies by 2050, with the highest real GDP growth in Sweden $(110 \%)$ and the lowest in Russia (93\%) (AMAP 2017, 11). However, the Barents Region is currently facing various challenges in terms of their economies. This includes demographic changes and outmigration from the Barents Region, higher unemployment, lack of access to quality higher education in remote communities, hindered transportation possibilities, income inequality, conflicts between indigenous and local communities vis-à-vis expanding mining and energy industries, as well as the collateral effect of the external events such as the financial crisis of the Ukrainian conflict.

There is certainly not an all-encompassing solution to these issues. Nonetheless, local action plans accompanied by a strong regional co-operation are required from nation states in order to improve the economic security of the population. Attractive living environments should also be promoted in the Barents Region in order to get people to move in, stay, or return to the region (BEAC 2014, 2). More precisely, there is an increasing need to create new employment possibilities, since unemployment, especially among young people, is quite high in some parts of the region. There is also a need to redefine the role of the elderly as active participants in the Barents economy (BIN 2017, 21). While access to better primary and secondary education must be improved, it is also important to support tertiary education in order to stimulate innovation and economic development in the region. Furthermore, transportation routes and infrastructure need to be developed throughout the region. Finally, innovation and industrial development must be enhanced, especially in the field of renewable nature-based industries in order to support sustainable economic development in the region. However, the benefits of development should be distributed to the population in a manner that benefits their interests at the local level and the protection of indigenous peoples' rights needs also to be guaranteed - a challenging task that will necessarily require policy and legislative reforms. Lastly, the region would benefit from stronger cooperation and further funding to support cross borders activities.

\section{Note}

1 Employed people are those aged 15 or over who report that they have worked in gainful employment for at least one hour in the previous week or who had a job but were absent from work during the reference week. The working age population refers to people aged 15 to 64 . 


\section{Anna Petrétei \& Dorothée Cambou}

\section{References}

Allard, C. 2006. Two Sides of the Coin: Rights and Duties - The Interface Between Environmental Law and Saami Law Based on a Comparison with Aoteoaroa/New Zealand and Canada. Sweden: Luleå.

AHDR 2004. Arctic Human Development Report. Akureyri, Iceland: Stefansson Arctic Institute.

AMAP (Arctic Monitoring and Assessment Programme). 2017. Barents Area Overview Report. Oslo, Norway: Adaptation Actions for a Changing Arctic (AACA) Barents Area Overview report. www.amap.no/documents/doc/Adaptation-Actionsfor-a-Changing-Arctic-AACA-Barents-Area-Overview-report/1529.

Anaya, J. 2010. Report of the Special Rapporteur on the Situation of Human Rights and Fundamental Freedoms of Indigenous People - Situation of Indigenous Peoples in the Russian Federation. A /HRC/15/37/Add.5. Human Rights Council. http://undocs. org/A/HRC/15/37/Add.5.

Anaya, J. 2011. Report on Extractive Industries Operating within or near Indigenous Territories. A/HRC/18/35. Human Rights Council. http://www.ohchr.org/Docum ents/Issues/IPeoples/SR/A-HRC-18-35_en.pdf.

BEAC Transport Area. 2013. Joint Barents Transport Plan - Proposals for Development of Transport Corridors for Further Studies. www.barentsinfo.fi/beac/docs/Joint_ Barents_Transport_Plan_2013.pdf.

BEAC. 2014. The Barents Programme 2014-2018. www.barentsinfo.fi/beac/docs/Ba rents_Programme_2014_2018_adopted_2_June_2013.pdf.

BEAC. 2015. Financing of Barents Cooperation - Report of the BEAC Ad Hoc Working Group on Financial Mechanism Study. Ministry for Foreign Affairs of Finland. www.barentsinfo.fi/beac/docs/LOW_UM_Barents_eJulkaisu_A5.pdf.

Bahry, D. 2002. Ethnicity and Equality in Post-communist Economic Transition: Evidence from Russia's Republics. Europe-Asia Studies 54(5): 673-699.

Business Index North (BIN), Bullvåg, E.et al.2017. A Periodic Report with Insight to Business Activity and Opportunities in the Arctic. http://www.kpb.no/sites/k/kpb.no/ files/businessindexnorth2017web.pdf

Dubiński, J. 2013. Sustainable Development of Mining Mineral Resources. Journal of Sustainable Mining 12(1): 1-6.

Duhaime, G. and Caron, A. 2009. Economic and Social Conditions of Arctic Regions 2008. In The Economy of the North, edited by S. Glomsrød and I. Aslaksen. Oslo: Statistics Norway.

Didyk, V. 2012. Sustainable Development and Local Self-government in the Russian Part of the Barents Region. In Politics of Development in the Barents Region, edited by M. Tennberg. Rovaniemi: LUP.

Eikeland, S. and Riabova, L. 2002. Transition in a Cold Climate: Management Regimes and Rural Marginalisation in Northwest Russia. Sociologia Ruralis 42(3): 255-266.

EU Commission. 2014. The 2015 Ageing Report - Underlying Assumptions and Projection Methodologies. European Economy 8|2014. European Economy Series. http://ec. europa.eu/economy_finance/publications/european_economy/2014/pdf/ee8_en.pdf.

Garipov, R. 2014. Extractive Industries and Indigenous Minority Peoples' Rights in Russia. Nordic Environmental Law Journal 1: 67-75.

Gentilini, U. and Omamo, W. 2009. Unveiling Social Safety Nets. Occasional Paper No 20. World Food Programme. https://www.wfp.org/sites/default/files/OP20\%20-\% 20Unveiling $\% 20$ Social $\% 20$ Safety $\% 20$ Nets $\% 20-\% 20$ English.pdf. 
Glomsrød, S. and Aslaksen, L. 2009. The Economy of the North 2008. Oslo: Statistics Norway.

Heinämäki, L. 2004. Environmental Rights Protecting the Way of Life of Arctic Indigenous Peoples: ILO Convention No. 169 and the UN Draft Declaration on Indigenous Peoples. In Arctic Governance, edited by T. Koivurova, T. Joona and R. Shrono. Rovaniemi: Juridica Lapponica 29.

ILO. 2004. ILO Socio-Economic Security Programme. www.ilo.org/public/english/p rotection/ses/download/docs/definition.pdf.

Koivurova, T. 2016. Analysis: The Arctic Conflict - Truth, Fantasy or a Little Bit of Both? High North News, November 18. www.highnorthnews.com/analysis-the-a rctic-conflict-truth-fantasy-or-a-little-bit-of-both/.

Koivurova, T, Masloboev, V., Hossain, K., Nygaard, V., Petrétei, A. and Vinogradova, S. 2015. Legal Protection of Sami Traditional Livelihoods from the Adverse Impacts of Mining: A Comparison of the Level of Protection Enjoyed by Sami in Their Four Home States. Arctic Review on Law and Politics 6(1): 11-51.

Larrabee, F.S., Pezard, S., Radin, A., Chandler, N., Crane, K. and Szayna, T. 2017. Russia and the West after the Ukrainian Crisis: European Vulnerabilities to Russian Pressures. RAND Corporation. www.rand.org/content/dam/rand/pubs/research_rep orts/RR1300/RR1305/RAND_RR1305.pdf.

Larsen, J. and Fondahl, G. 2015. Arctic Human Development Report. Copenhagen: Nordic Council of Ministers.

Nilsen, T. 2014. Ukraine Crisis Hurts Russian Tourism. Barents Observer, May 8. http://barentsobserver.com/en/business/2014/05/ukraine-crisis-hurts-russian-tourism08-05.

Nilsen, T. 2016. EU Has No Plans to Lift Russia Sanctions. The Independent Barents Observer, November 16. https://thebarentsobserver.com/en/life-and-public/2016/11/ eu-has-no-plans-lift-russia-sanctions.

Norwegian Ministry of Trade and Industry. 2013. Strategy for the Mineral Industry. www.regjeringen.no/contentassets/3fe548d142cd496ebb7230a54e71ae1a/strategy forthemineralindustry_2013.pdf.

Pettersson, M., Oksanen, A., Mingaleva, T., Petrov, V. and Masloboev, V. 2015. License to Mine: A Comparison of the Scope of the Environmental Assessment in Sweden, Finland and Russia. Natural Resources 6: 237-255.

Russel, M. 2016. Sanctions over Ukraine: Impact on Russia. PE 579.084. European Parliamentary Research Service. European Parliament. www.europarl.europa.eu/ EPRS/EPRS-Briefing-579084-Sanctions-over-Ukraine-impact-Russia-FINAL.pdf.

Sen, A. 1983. Development: Which Way Now? The Economic Journal 93(372): 745-762.

Skogvang, S. F. 2013. Legal Questions Regarding Mineral Exploration and Exploitation in Indigenous Areas. Michigan State University College of Law Journal of International Law 22(1): 321-345.

Swedish Ministry of Enterprise, Energy and Communications. 2013. Sweden's Minerals Strategy - For Sustainable Use of Sweden's Mineral Resources That Creates Growth throughout the Country. http://www.government.se/49b757/contentassets/ 78bb6c6324bf43158d7c153ebf2a4611/swedens-minerals-strategy.-for-sustainable-useof-swedens-mineral-resources-that-creates-growth-throughout-the-country-completeversion.

Tauli-Corpuz, V. 2016. Report of the Special Rapporteur on the Rights of Indigenous Peoples on the Human Rights Situation of the Sami People in the Sápmi Region of Norway, Sweden and Finland. A /HRC/ $33 / 42$ /Add. 3. United Nations General 


\section{Anna Petrétei \& Dorothée Cambou}

Assembly. http://unsr.vtaulicorpuz.org/site/images/docs/country/2016-sapmi-a-hrc33-42-add-3-en.pdf.

United Nations. 2017. Human Development Index. http://hdr.undp.org/en/content/ human-development-index-hdi

UNDP. 1994. Human Development Report. New York: Oxford University Press.

UNDP. 2016. Human Development Report 2016 - Human Development for Everyone. www.hdr.undp.org/sites/default/files/2016_human_development_report.pdf.

World Bank Group. 2016. Russia Economic Report No. 35 I April 2016 The Long Journey to Recovery. http://pubdocs.worldbank.org/en/481881460390188506/rer35ENG.pdf. 